Syntax Idea: p-ISSN: 2684-6853 e-ISSN: 2684-883X

Vol. 3, No.10, Oktober 2021

\title{
KUALITAS SOAL UJIAN AKHIR SEKOLAH MATA FISIKA SMA NEGERI SE- KOTA BAUBAU
}

\section{Minarti Usman}

Sekolah Tinggi Agama Islam (STAI) YPIQ Baubau Sulawesi Tenggara, Indonesia Email: minarti393@gmail.com

\begin{abstract}
Abstrak
Dalam rangka pencapaian tujuan pendidikan nasional maka pemerintah berupaya meningkatkan mutu pendidikan mulai dari jenjang sekolah dasar sampai perguruan tinggi. Penelitian ini bertujuan untuk mengetahui kualitas soal Ujian Akhir Sekolah mata pelajaran fisika kelas XII IPA SMA Negeri di Kota Baubau Tahun Pelajaran 2017/2018 dengan melihat validitas, reliabilitas, tingkat kesukaran, daya beda dan efektivitas pengecohnya. Jenis penelitian yang digunakan adalah penelitian deskriptif kuantitatif dengan subjek penelitian lembar jawaban hasil ujian akhir sekolah mata pelajaran fisika kelas XII IPA SMA Negeri se-Kota Baubau yang terdiri dari 400 peserta didik. Hasil penelitian menunjukkan validitas isi soal ujian akhir sekolah mata pelajaran fisika kelas XII IPA SMA Negeri se-Kota Baubau telah valid secara isi dengan koefisien validitas sebesar 0,943, validitas kriteria soal ujian akhir sekolah mata pelajaran fisika kelas XII IPA SMA Negeri se-Kota Baubau terdapat 9 butir soal tidak valid dari 35 butir soal yang diujikan, tingkat kesukaran soal ujian akhir sekolah mata pelajaran fisika kelas XII IPA SMA Negeri se-Kota Baubau memiliki sebaran tingkat kesukaran yang tidak proporsional dengan perbandingan sukar, sedang, dan mudah adalah 12, 2, dan 21, daya beda soal ujian akhir sekolah mata pelajaran fisika kelas XII IPA SMA Negeri se-Kota Baubau terdapat 14 butir soal yang memiliki daya beda sangat baik, 6 butir soal dengan daya beda baik, 1 butir soal dengan daya beda kurang baik dan 14 butir soal yang memiliki daya beda tidak berfungsi, efektivitas pengecoh, soal ujian akhir sekolah mata pelajaran fisika kelas XII IPA SMA Negeri se-Kota Baubau secara keseluruhan tidak dapat dapat dikatakan efektif atau berfungsi karena dari 35 butir soal yang di ujikan hanya terdapat 2 butir soal yang efektivitas pengecohnya berfungsi, dan reliabilitas, instrumen soal ujian akhir sekolah mata pelajaran fisika kelas XII IPA SMA Negeri se-Kota Baubau reliabel atau konsisten dengan koefosien reliabilitas instrument sebesar 0,741 .
\end{abstract}

Kata Kunci: validitas; tingkat kesukaran; daya beda; efektivitas pengecoh; reliabilitas

\section{Abstract}

In order to achieve national education goals, the government seeks to improve the quality of education ranging from elementary school to college level. This research aims to find out the quality of the Final Exam of the School physics subjects class XII IPA State High School in Baubau City 2017/2018 by looking at the validity, reliability, difficulty level, different power and effectiveness of the cheater. The type of research used is quantitative descriptive research with the subject of the study sheet answering the final exam results of the school physics class XII IPA State

$\begin{array}{ll}\text { How to cite: } & \text { Usman. M., (2021) Kualitas Soal Ujian Akhir Sekolah Mata Fisika SMA Negeri Se- Kota Baubau, } \\ & \text { Syntax Idea. 3(10), https://doi.org/10.36418/syntax-idea.v3i10.1527 } \\ \text { E-ISSN: } & \text { 2684-883X } \\ \text { Published by: } & \text { Ridwan Institute }\end{array}$


High School in Baubau City consisting of 400 learners. The results showed the validity of the contents of the final exam questions of the physics subjects of class XII IPA State High School in Baubau City has been valid in content with a validity coefficient of 0.943, the validity of the criteria for the final exam of the physics subject class XII IPA State High School in Baubau City there are 9 points of invalid question from 35 points of question tested, The difficulty level of the final exam of the physics subject class XII State High School IPA in Baubau City has a disproportionate distribution of difficulty levels with difficult, medium, and easy comparisons are 12, 2, and 21, the other power of the final exam of the physics exam class XII IPA State High School in Baubau City there are 14 points of questions that have very good different power, 6 points of questions with different power, 1 point of questions with less good different power and 14 points of questions that have different power does not work, the effectiveness of the cheater, the final exam question of physics class XII IPA State High School in Baubau City as a whole cannot be said to be effective or functional because of the 35 points of questions tested there are only 2 questions whose effectiveness of the cheater works, and reliability, instruments about the final exam of the physics subjects of physics class XII IPA Sma Negeri in Baubau City are reliable or consistent with the koefosien reliability instrument of 0.741 .

Keywords: validity; difficulty level; differentiating power; effectiveness of distracter; keandalan

\section{Received: 2021-09-22; Accepted: 2021-10-05; Published: 2021-10-20}

\section{Pendahuluan}

Tujuan Pendidikan Nasional dalam Undang-Undang N0. 20, tahun 2003 Pasal 3 menyebutkan, "Pendidikan nasional berfungsi mengembangkan kemampuan dan membentuk watak serta peradaban bangsa yang bermartabat dalam rangka mencerdaskan kehidupan bangsa, bertujuan untuk berkembangnya potensi peserta didik agar menjadi manusia yang beriman dan bertakwa kepada Tuhan Yang Maha Esa, berakhlak mulia, sehat, berilmu, cakap, kreatif, mandiri, dan menjadi warga negara yang demokratis serta bertanggung jawab."

Dalam rangka pencapaian tujuan pendidikan nasional maka pemerintah berupaya meningkatkan mutu pendidikan mulai dari jenjang sekolah dasar sampai perguruan tinggi. Salah satu jenjang pendidikan tersebut adalah sekolah menengah atas (Yuningsih, 2015).

Mengajar atau mendidik adalah memberikan bimbingan belajar kepada peserta didik. Pemberian bimbingan menjadi kegiatan belajar seperti mendengar ceramah, membaca buku, melihat demonstrasi, menyaksikan pertandingan, mengarang dan sebagainya, dan peranan guru mengarahkan, mempersiapkan, mengontrol dan memimpin sang anak agar kegiatan belajar mengajarnya berhasil (Fahmi, 2018).

Berdasarkan Permendikbud Nomor 3 Tahun 2017 tentang penilaian hasil belajar oleh pemerintah dan penilaian hasil belajar oleh satuan pendidikan, bahwa soal-soal USBN dibuat oleh guru-guru sekolah yang tergabung dalam Musyawarah Guru Mata 
Pelajaran (MGMP) dengan mengacu pada kisi-kisi yang dikeluarkan oleh BSNP (Kartini, 2018).

Harapan untuk menyelenggarakan ujian nasional dan ujian sekolah dengan baik tampaknya masih menemui beberapa kendala. Seperti yang pernah terjadi di Kota Kendari saat pelaksanaan ujian nasional tahun 2009 yang tidak efektif hal ini dikarenakan adanya soal dan kunci jawaban yang bocor, sehingga BSNP mengeluarkan keputusan tentang diadakannya Ujian Nasional ulang bagi seluruh SMP dan MTS seKota Kendari serta SMA 5 Kendari. Penyelenggaraan UN ulang tersebut berdasarkan surat Badan Standarisasi Nasional Pendidikan (BSNP) nomor 16/SK-UN/BSNP/V/2009 untuk SMP dan nomor 17/SK- UN/BSNP/V/2009 untuk SMA/MA (Mastuti et al., 2020).

Bocornya naskah soal Ujuan Nasional (UN) SMA/MA dan SMP/MTS tahun 2009 tentunya menurunkan kredibilitas penyelenggara ujian nasional. Ujian Nasional yang seharusnya sebagai barometer terhadap kualitas intelektual bagi para pelajar seIndonesia pada umumnya dan se-SULTRA pada khususnya, ternyata sangat jauh dari fakta yang ada dilapangan.

Berdasarkan informasi yang diperoleh dari beberapa guru fisika yang tergabung dalam Musyawarah Guru Mata Pelajaran (MGMP) di kota Baubau bahwa soal Ujian Akhir Sekolah (UAS) belum pernah dilakukan analisis kualitas soal fisika yang dijadikan sebagai alat ukur untuk mengukur tingkat pencapaian kompetensi peserta didik dalam UAS mata pelajaran Fisika sehingga kualitas soal yang diujikan masih belum diketahui apakah sudah termasuk butir soal yang memenuhi syarat sebagai alat ukur yang baik atau belum.

Dengan melihat latar belakang permasalahan diatas, maka penulis tertarik untuk melakukan penelitian lebih lanjut terkait kualitas soal USBN mata pelajaran fisika di SMA Negeri Kota Baubau. Adapun judul yang diajukan peneliti adalah Kualitas Soal Ujian Akhir Sekolah Fisika SMA Negeri Se-Kota Baubau.

Analisis data merupakan suatu proses tindakan merubah data mentah menjadi data yang telah diolah atau informasi yang berguna untuk menambah nilai dan manfaat pada hasil evaluasi.

Analisis data dimulai pada penyusunan desain evaluasi. Menurut (Otaya, 2014), Analisis kualitas soal merupakan upaya penting dalam membuat instrumen penilaian dengan kategori baik. Dengan menggunakan analisis kualitas soal, dapat diidentifikasi butir-butir soal yang termasuk dalam kategori baik, kurang baik, dan bahkan buruk. Analisis kualitas soal juga memungkinkan untuk memperoleh informasi penilaian tentang baik tidaknya suatu soal, dan juga mendapatkan petunjuk untuk melakukan perbaikan soal yang ditulis atau disusun. Kegiatan menganalisis kualitas instrumen merupakan suatu kegiatan yang harus dilakukan guna meningkatkan mutu soal yang telah ditulis.

Menurut (Sudjana, 2009), Analisis kualitas soal merupakan prosedur sitematis yang digunakan dengan tujuan akan memperoleh informasi-informasi khusus terhadap butir tes yang telah disusun untuk mengkaji dan menelaah setiap soal tes agar diperoleh 
soal yang bermutu untuk dapat digunakan. Disamping itu tujuan analisis kualitas butir soal juga adalah untuk memberikan gambaran informasi yang tepat sesuai dengan tujuan soal tersebut.

Menurut (Wirawan, 2016), kesuksesan analisis data memerlukan:

1. Pemahaman berbagai metode analisis data

2. Perencanaan analisis data pada awal proyek evaluasi

3. Pemahaman metode-metode mana yang terbaik untuk menjawab pertanyaan yang dikemukakan berdasarkan data yang telah dikumpulkan

4. Jika analisis selesai, mengetahui bagaimana kelemahan-kelemahan data atau analisis mempengaruhi kesimpulan yang dapat ditarik.

Menurut (Kurniawan, 2015), tujuan utama analisis soal dalam sebuah tes yang dibuat guru adalah suatu bentuk tes yang digunakan untuk mendapatkan data, sebagai bahan informasi tentang seberapa besar pengetahuan yang telah dimiliki dan dikuasai oleh peserta tes. Jika didasarkan pada tujuan tersebut, maka kegiatan analisis butir soal memiliki banyak manfaat, di antaranya adalah: (1) menentukan apakah suatu fungsi butir soal sesuai dengan yang diharapkan, (2) memberi masukan kepada peserta didik tentang kemampuan dan sebagai dasar untuk bahan diskusi di kelas, (3) memberi masukan kepada guru tentang kesulitan peserta didik, (4) memberi masukan pada aspek tertentu untuk pengembangan kurikulum, (5) merevisi materi yang dinilai atau diukur, (6) meningkatkan keterampilan penulisan soal.

\section{Metode Penelitian}

Penelitian ini adalah penelitian deskriptif kuantitatif yang bertujuan untuk menggambarkan objek penelitian mengenai kualitas soal UAS SMA Negeri Kota Baubau yang ditinjau mulai dari validitas, reliabilitas, tingkat kesukaran, daya pembeda dan efektifitas pengecoh.

Sumber data dalam penelitian ini adalah lembar jawaban peserta UAS pada soal mata pelajaran fisika di SMA Negeri di Kota Baubau tahun pelajaran 2017/2018. Sumber data berupa dokumentasi lembar jawaban peserta didik mata pelajaran fisika ujian akhir sekolah tahun pelajaran 2017/2018.

Subjek dalam penelitian ini adalah seluruh lembar jawaban peserta didik kelas XII IPA di empat SMA Negeri di Kota Baubau tahun ajaran 2017/2018 yaitu SMA Negeri 1 Baubau, SMA Negeri 3 Baubau, SMA Negeri 5 Baubau, dan SMA Negeri 6 Baubau. Teknik purposif sampling digunakan dalam pemilihan subjek dalam penelitian ini.

Teknik pengumpulan data pada penelitian ini adalah menggunakan teknik dokumentasi, yaitu dengan mengutip lembar jawaban peserta UAS pada mata pelajaran fisika kelas XII IPA di SMA.

\section{Hasil dan Pembahasan}

a. Validitas Isi

Hasil validitas isi instrumen tes Ujian Akhir Sekolah mata pelajaran Fisika di SMA Se-Kota Baubau Tahun Ajaran 2017/2018 ditunjukan dalam table 1 berikut: 
Tabel 1

Hasil Validitas Isi

\section{Hasil Validitas Isi Pakar}

Valid Direvisi

Koefisien

Validitas Isi

$2,3,4,5$, $6,7,8,9$,

$10,11,12$,

$14,15,16$,

$17,18,19$,

$20,21,22$,

$23,24,25$,

$26,27,28$,

$29,30,31$,

$32,33,34$,

dan 35

Berdasarkan Tabel 1 Hasil validitas isi soal Ujian Akhir Sekolah mata pelajaran Fisika Kelas XII IPA SMA Negeri Se-kota Baubau, diperoleh soal yang valid sebanyak 33 butir soal dan soal yang tidak valid sebanyak 2 butir soal dari 35 butir soal secara keseluruhan. Hal tersebut dapat dilihat bahwa soal yang berada dalam sel D (sangat relevan) sebanyak 33 butir soal yaitu soal dengan nomor $2,3,4,5,6,7,8,9,10,11,12$, 14, 15, 16, 17, 18, 19, 20, 21, 22, 23, 24, 25, 26, 27, 28, 29, 30, 31, 32, 33, 34 dan 35.

Soal berada dalam sel D artinya kesdua pakar/validator sepakat bahwa soal tersebut telah relevan dengan SKL, KD, Indikator dan tingkat kognitif, sehingga diperoleh koefisien validitas isi sebesar 0,943. Artinya 94,3\% dari total jumlah soal telah relevan dengan SKL, KD, indikator dan tingkat kognitif.

b. Validitas Kriteria

Hasil validitas kriteria instrumen tes Ujian Akhir Sekolah mata pelajaran Fisika di SMA Se-Kota Baubau Tahun Ajaran 2017/2018 ditunjukan dalam tabel 2 berikut:

Tabel 2

Hasil Klasifikasi Validitasi Kriteria Soal Ujian Akhir Sekolah

\begin{tabular}{cccc}
\hline Kriteria & $\begin{array}{c}\text { Nomor Butir } \\
\text { Soal }\end{array}$ & Jumlah & $\begin{array}{c}\text { Persentase } \\
(\boldsymbol{\%})\end{array}$ \\
\hline $1,2,3$, & \\
\hline $6,7,8$, \\
\hline 9, 11, \\
\hline 12,13, \\
\hline 14,15, \\
\hline 16,17, \\
\hline \multicolumn{3}{c}{26} \\
\hline 20,21, \\
\hline
\end{tabular}




\begin{tabular}{|c|c|c|c|}
\hline Kriteria & $\begin{array}{c}\begin{array}{c}\text { Nomor Butir } \\
\text { Soal }\end{array} \\
\end{array}$ & Jumlah & $\begin{array}{c}\text { Persentase } \\
(\%)\end{array}$ \\
\hline \multicolumn{4}{|c|}{28,29,} \\
\hline \multicolumn{4}{|c|}{30,31 , } \\
\hline \multicolumn{4}{|c|}{32,35} \\
\hline \multicolumn{4}{|l|}{ Tidak Valid } \\
\hline & 24,25 & 9 & 25,71 \\
\hline \multicolumn{4}{|c|}{26,27} \\
\hline & 33,34 & & \\
\hline
\end{tabular}

Berdasarkan Tabel 2 Hasil klasifikasi validitas kriterian soal Ujian Akhir Sekolah mata pelajaran Fisika Kelas XII IPA SMA Negeri Se-kota Baubau, diperoleh soal yang valid sebanyak 26 butir soal dengan persentase $74,29 \%$ dan soal yang tidak valid sebanyak 9 butir dengan persentase $25,71 \%$. Hal ini menunjukkan bahwa berdasarkan persentase validitas kriteria soal Ujian Akhir Sekolah mata pelajaran fisika kelas XII IPA SMA Negeri se-Kota Baubau secara belum dapat dikatakan valid karena masih terdapat 9 butir soal $(25,71 \%)$ yang tidak valid.

c. Tingkat Kesukaran

Hasil klasifikasi tingkat kesukaran soal ujian akhir sekolah mata pelajaran fisika SMA Negeri se-Kota Baubau Tahun ajaran 2017/2018 di sajikan pada tabel 4.3 berikut:

Tabel 3

Hasil Klasifikasi Tingkat Kesukaran Soal Ujian Akhir Sekolah

\begin{tabular}{cccc}
\hline Kriteria & $\begin{array}{c}\text { Nomor } \\
\text { Butir Soal }\end{array}$ & Jumlah & $\begin{array}{c}\text { Persentase } \\
(\%)\end{array}$ \\
\hline \multirow{4}{*}{ Sukar } & $4,5,10$, & & \\
& 14,15, & & \\
& 24,25, & 12 & $34,29 \%$ \\
& 26,27, & & \\
& 31,33, & & \\
Sedang & 2 dan 34 & & \\
& 2 dan 7 & 2 & $5,71 \%$ \\
& $1,3,6,8$, & & \\
& $9,11,12$, & & \\
& 13,16, & & \\
& 17,18, & & \\
Mudah & 19,20, & 21 & \\
& 21,22, & & \\
& 23,28, & & \\
& 29,30, & & \\
& 32, dan & & \\
& 35 & & \\
\end{tabular}


Berdasarkan Tabel 3 hasil klasifikasi tingkat kesukaran soal ujian akhir sekolah mata pelajaran fisika kelas XII IPA SMA Negeri se-Kota Baubau, diperoleh butir soal pada tingkat kesukaran sukar sebanyak 12 butir dengan persentase 34,29\%, butir soal pada tingkat kesukaran sedang sebanyak 2 butir dengan persentase sebanyak $5,71 \%$ dan butir soal pada tingkat kesukaran mudah sebanyak 21 butir dengan persentase $60 \%$. Dari data tersebut diperoleh perbandingan tingkat kesukaran soal pada kategori sukar, sedang dan mudah adalah 34,29\%: 5,71\%: $60 \%$.

d. Daya Beda

Hasil klasifikasi daya pembeda soal ujian akhir sekolah mata pelajaran fisika kelas XII IPA SMA Negeri se-Kota Baubau Tahun ajaran 2017/2018 di sajikan pada tabel 4 berikut:

\section{Tabel 4}

\section{Hasil Klasifikasi Daya Beda Soal Ujian Akhir Sekolah}

\begin{tabular}{|c|c|c|c|}
\hline Kriteria & $\begin{array}{c}\text { Nomor } \\
\text { Butir } \\
\text { Soal }\end{array}$ & Jumlah & $\begin{array}{c}\text { Persentase } \\
(\%)\end{array}$ \\
\hline $\begin{array}{l}\text { Sangat } \\
\text { baik }\end{array}$ & $\begin{array}{c}1,3,6, \\
8,12, \\
17,18, \\
19,21, \\
22,23, \\
28,30, \\
\text { dan } 32\end{array}$ & 14 & $40 \%$ \\
\hline Baik & $\begin{array}{c}9,11, \\
15,20 \\
29, \text { dan } \\
35\end{array}$ & 6 & $17,14 \%$ \\
\hline $\begin{array}{c}\text { Kurang } \\
\text { baik }\end{array}$ & 13 & 1 & $2,86 \%$ \\
\hline $\begin{array}{c}\text { Tidak } \\
\text { berfungsi }\end{array}$ & $\begin{array}{c}2,4,5, \\
7,10, \\
14,16, \\
24,25, \\
26,27, \\
31,33, \\
\text { dan } 34\end{array}$ & 14 & 40 \\
\hline
\end{tabular}

Soal yang baik adalah soal yang memiliki daya pembeda antara kelompok atas dan kelompok rendah. Berdasarkan Tabel 4.4 hasil klasifikasi daya beda soal ujian akhir sekolah mata pelajaran fisika SMA kelas XII IPA Negeri se-Kota Baubau diperoleh daya beda soal dengan kategori sangat baik yaitu 14 butir (40\%), kategori baik yaitu 6 butir $(17,14 \%)$, kategori kurang baik yaitu 1 butir $(2,86 \%)$ dan kategori tidak berfungsi yaitu 14 butir (40\%). 
e. Efektivitas Pengecoh

Hasil klasifikasi efektivitas pengecoh soal ujian akhir sekolah mata pelajaran fisika kelas XII IPA SMA Negeri se-Kota Baubau Tahun ajaran 2017/2018 di sajikan pada tabel 5 berikut:

\section{Tabel 5}

Hasil Klasifikasi Efektivitas Pengecoh Soal Ujian Akhir Sekolah

\begin{tabular}{cccc}
\hline Kriteria & $\begin{array}{c}\text { Nomor } \\
\text { Butir } \\
\text { Soal }\end{array}$ & Jumlah & $\begin{array}{c}\text { Persentase } \\
(\%)\end{array}$ \\
\hline Efektif & $\begin{array}{c}16 \text { dan } \\
34\end{array}$ & 2 & $5,71 \%$ \\
& $1,2,3$, & & \\
& $4,5,6$, & & \\
& $7,8,9$, & & \\
& 10,11, & & \\
& 12,13, & & \\
& 15,16, & & \\
Tidak & 17,18, & & \\
Efektif & 19,20, & 33 & \\
& 21,22, & & \\
& 23,24, & & \\
& 25,26, & & \\
& 27,28, & & \\
& 29,30, & & \\
& 31,32, & \\
& 33, dan & \\
& 35 & \\
\hline
\end{tabular}

Berdasarkan tabel 5, diperoleh bahwa butir soal yang pengecohnya tidak efektif atau tidak berfungsi lebih banyak daripada soal yang pengecohnya berfungsi dimana soal yang pengecohnya berfungsi sebanyak 2 butir $(5,71 \%)$ yaitu soal nomor 16 dan soal nomor 34 sedangkan soal yang pengecohnya tidak berfungsi sebanyak 33 butir $(94 \%)$.

f. Reliabilitas

Koefisien reliabilitas skor tes dilakukan dengan memberikan tes secara tunggal (sekali uji) yang disebut dengan metode koefisien alpha atau Kuder- Richardson dengan satu format tes. Koefisien reliabilitas diperoleh setelah menggunakan aplikasi Iteman yaitu sebesar 0,741 dimana $\rho K R-20>0,7$, sehingga instrument tes soal ujian akhir sekolah mata pelajaran fisika kelas XII IPA SMA se-Kota Baubau dapat dikatakan konsisten. Adapun pembahasan hasil penelitian tersebut adalah sebagai berikut: 
a. Validitas isi soal ujian akhir sekolah mata pelajaran fisika kelas XII IPA SMA Negeri di Kota Baubau

Pengujian validitas isi soal ujian akhir sekolah mata pelajaran fisika kelas XII IPA SMA Negeri se-Kota Baubau di laksanakan guna menjawab pertanyaan penelitian nomor pertama terkait validitas intrumen. Berdasarkan hasil penelitian yang melalui proses validitas isi yakni penilaian pakar/ validator diperoleh soal yang valid sebanyak 33 butir soal sehingga diperoleh koefisien validitas sebesar 0,943 .

Hasil penelitian tersebut di dukung oleh pernyataan dari Gregory dalam (Sudaryono, 2017) yang mengemukakan bahwa, "validitas isi menunjukkan sejauh mana pertanyaan, tugas atau butir dalam suatu tes atau isntrumen mampu mewakili secara keseluruhan dan proporsional keseluruhan prilaku sampel yang menjadi tujuan pembelajaran yang akan diukur pencapaiannya". Pernyataan tersebut juga didukung oleh (Kurniawan, 2015) yang menyatakan bahwa suatu tes dikatakan memiliki validitas isi, apabila butir-butir yang disusun sesuai dengan materi-materi pelajaran dan indikator yang telah ditetapkan. Kemudian jika hasil penelitian di kaitkan dengan kajian teoritis yang telah dikemukakan dapat dikatakan bahwa soal ujian akhir sekolah mata pelajaran fisika kelas XII IPA SMA Negeri se-Kota Baubau telah memenuhi aspek kualitas validitas isi.

Adapun 2 nomor butir soal yang memiliki relevansi lemah yakni soal nomor 1 dan nomor 13 peneliti disarankan agar merevisi atau membuang soal tersebut sehingga instrumen ini dapat digunakan seluruhnya.

b. Validitas kriteria soal ujian akhir sekolah mata pelajaran fisika kelas XII IPA SMA Negeri di Kota Baubau

Berdasarkan hasil penelitian, soal ujian akhir sekolah mata pelajaran fisika kelas XII IPA SMA Negeri se-Kota Baubau secara keseluruhan sudah dapat dikatakan valid meskipun masih terdapat $9(25,71 \%)$ soal yang tidak valid. Hal ini didukung dengan adanya teori validitas yang dikemukakan oleh (Ristiyani \& Bahriah, 2016) bahwa butir soal yang memiliki validitas yang tinggi mencerminkan soal tersebut telah memiliki kehandalan dan tidak perlu diragukan keakuratan dalam mengukur kemampuan peserta didik. Untuk butir soal yang memiliki validitas yang rendah dapat diartikan bahwa soal tersebut tidak valid sehingga perlu dilakukan tindakan perbaikan terhadap soal tersebut.

Soal ujian akhir sekolah mata pelajaran fisika kelas XII IPA SMA Negeri se-Kota Baubau dikatakan valid jika butir soal tersebut benar-banar mengukur sasaran tes berupa kemampuan dalam bidang fisika dengan kata lain mampu mengukur apa yang ingin diukur terkait dengan hubungan skor butir dengan skor totalnya. Jika hasil penelitian ini dihubungkan dengan tinjauan teoretis sebagaimana yang dikemukakan oleh (Sukardi et al., 2008) bahwa, "Validitas mengarah pada alat ukur suatu penilaian untuk mengukur atau mengungkap apa yang akan diukur dan valid dapat diartikan sebagai ketepatan penafsiran yang dihasilkan dari skor tes atau instrumen penilaian". Didiukung pula oleh 
pernyataan (Sukardi et al., 2008) bahwa, "Suatu butir dinyatakan valid apabila memiliki sumbangan yang besar terhadap skor totalnya.

c. Tingkat kesukaran soal ujian akhir sekolah mata pelajaran fisika kelas XII IPA SMA Negeri di Kota Baubau

Analisis soal ujian akhir sekolah mata pelajaran fisika kelas XII IPA SMA Negeri di Kota Baubau jika ditinjau dari tingkat kesukaran, diperoleh hasil penelitian diperoleh butir soal yang berada pada tingkat kesukaran sukar sebanyak $12(34,29 \%)$ butir, butir soal yang berada pada tingkat kesukaran sedang sebanyak $2(5,71 \%)$ butir dan butir soal yang berada pada kategori mudah sebanyak 21 (60\%) butir. Apabila dianalisis berdasarkan tingkat kognitif, diketahui bahwa tingkat kognitif pada butir soal yang berada dikategori tingkat kesukaran sukar yaitu dari 12 butir soal terdapat 3 soal $(4,5$, dan 34) berada pada tingkat kognitif penalaran (K3), 8 soal $(10,14,15,25,26,27,31$, dan 33) berada pada tingkat kognitif aplikasi (K2) serta 1 soal (24) yang berada pada tingkat kognitif pengetahuan dan pemahaman (K1).

Hasil penelitian tersebut kemudian dihubungkan dengan kajian teoritis dikemukakan oleh (Sudjana, 2009), bahwa soal yang baik memiliki tingkat kesukaran dengan perbandingan antara soal mudah : sedang : sukar yaitu 3:4:3, yaitu 30\% soal kategori mudah, 40\% kategori sedang dan 30\% kategori sukar atau 3:5:2, yaitu 30\% soal kategori mudah, 50\% kategori sedang dan 20\% kategori sukar. Didukung juga penjelasan (Erniwati, 2018) bahwa "untuk menentukan proporsi jumlah soal kategori sukar, sedang dan mudah yaitu dengan dengan mempertimbangkan keseimbangan jumlah anatara ketiga kategori tersebut serta didasarkan atas kurva normal.

Dengan demikian bahwa sebaran hasil penelitian pada tingkat kesukaran soal ujian akhir sekolah mata pelajaran fisika kelas XII IPA SMA Negeri di Kota Baubau belum proporsional dikarenakan butir soal lebih banyak berada pada tingkat kesukaran mudah, kemudian sukar dan terakhir sedang hal ini tidak sesuai dengan syarat soal yang baik jika ditinjau dari tingkat kesukaran. Sebagaimana dikemukakan oleh (Suseno, 2017) bahwa uji tes sangat bergantung pada butir dan peserta tes.

d. Daya beda soal ujian akhir sekolah mata pelajaran fisika kelas XII IPA SMA Negeri di Kota Baubau

Analisis soal ujian akhir sekolah mata pelajaran fisika kelas XII IPA SMA Negeri di Kota Baubau jika ditinjau dari daya beda, diperoleh daya beda soal dengan kategori sangat baik yaitu 14 butir (40\%), kategori baik yaitu 6 butir $(17,14 \%)$, kategori kurang baik yaitu 1 butir $(2,86 \%)$ dan kategori tidak berfungsi yaitu 14 butir (40\%).

Hasil penelitian tersebut kemudian dihubungkan dengan kajian teoritis yang dikemukakan oleh (Suseno, 2017), bahwa daya beda butir adalah kemampuan butir menunjukkan kelompok sekor tinggi melalui banyak jawaban betul serta menunjukkan kelompok rendah melalui sedikit jawaban betul. Hal 
yang sama juga diungkapkan oleh (Sari, Rakimahwati, \& Fitria, 2019), menjelaskan bahwa daya beda harus harus diusahakan setinggi mungkin, karena soal yang mempunyai daya beda tinggi berarti soal tersebut dapat membedakan dengan baik antara siswa kelompok atas dan bawah. Perbedaan skor yang dihasilkan oleh kelompok tinggi dan kelompok rendah dipengaruhi tinggi rendahnya daya pembeda butir tes. Hal ini dikarenakan fungsi dari daya pembeda tersebut adalah untuk mengetahui perbedaan tiap individu yang sekecil-kecilnya di antara para peserta tes.

Berdasarkan hasil analisis data daya beda soal ujian akhir sekolah mata pelajaran fisika kelas XII IPA SMA Negeri di Kota Baubau diperoleh bahwa daya pembeda dari 35 soal yang dianalisis terdapat 14 soal pada kategori sangat baik, 6 soal kategori baik, 1 soal kategori kurang baik dan 14 soal pada kategori buruk (tidak berfungsi). Dari indeks diskriminasi ditunjukkan bahwa terdapat 11 butir soal yang mempunyai indeks daya beda negative yaitu soal nomor 2, 4, 5, 10, 24, 25, 26, 27, 31, 33, dan 34. Hal ini mempunyai arti bahwa butir-butir tersebut sukar bagi kelompok atas tetapi tergolong mudah bagi kelompok bawah atau dengan kata lain kelompok bawah lebih banyak yang menjawab benar daripada kelompok atas. Hal tersebut dapat diartikan bahwa butir-butir soal tersebut mempunyai daya pembeda yang terbalik, yang artinya soal tersebut tidak baik jika dilihat dari daya pembedanya. Terdapat beberapa faktor yang membuat suatu butir mempunyai indeks daya beda rendah atau bahkan buruk, seperti yang dikemukakan oleh (Mutia, Budi, \& Serevina, 2014) bahwa ada dua kondisi yang menyebabkan suatu butir memiliki daya rendah yaitu semua peserta tes mampu menjawab karena butir tersebut terlalu mudah atau sebaliknya, semua peserta tidak mampu menjawab benar karena butir tersebut terlalu sukar.

Hasil analisis menunjukkan bahwa $40 \%$ butir soal ujian akhir sekolah mata pelajaran fisika di Kota Baubau memiliki daya beda sangat baik dan 17,14\% butir soal ujian akhir sekolah mata pelajaran fisika kelas XII IPA SMA Negeri di Kota Baubau memiliki daya beda baik sehingga secara keseluruhan soal ujian akhir sekolah mata pelajaran fisika kelas XII IPA SMA se-Kota Baubau dapat membedakan peserta tes berkemampuan rendah dengan peserta tes berkemampuan tinggi.

e. Efektivitas pengecoh soal ujian akhir sekolah mata pelajaran fisika kelas XII IPA SMA Negeri di Kota Baubau.

Suatu pola yang menggambarkan bagaimana peserta menentukan pilihan jawabannya terhadap kemungkinan- kemungkinan jawaban yang telah dipasangkan pada setiap butir item adalah pengertian dari distraktor.

Distraktor/pengecoh dikatakan sudah menjalankan fungsinya dengan baik apabila distraktor/pengecoh tersebut sekurang-kurangnya dipilih oleh 5\% dari seluruh peserta tes atau 34 apabila mempunyai daya tarik yang besar bagi peserta tes yang kurang memahami konsep materi atau kurang menguasai bahan 
(kelompok bawah). Untuk menentukan angka pedoman efektifitas distractor/pengecoh dapat ditentukan dengan cara perkalian antara 5\% X Jumlah peserta tes. Berdasarkan hasil analisis soal ujian akhir sekolah mata pelajaran fisika kelas XII IPA SMA Negeri di Kota Baubau jika ditinjau dari efektivitas pengecoh, diperoleh butir soal yang pengecohnya berfungsi sebanyak $2(5,71 \%)$ butir yaitu butir nomor 16 dan 34, dan butir soal yang pengecohnya tidak berfungsi sebanyak 33 (94,29\%). Jika melihat dari hasil analisis tersebut peserta ideal. Pengecoh dapat dikatakan berfungsi apabila pengecoh paling tidak dipilih oleh $5 \%$ peserta tes dan pengecoh lebih banyak dipilih oleh kelompok peserta didik yang belum mememahami materi yang diajarkan".

f. Reliabilitas soal ujian akhir sekolah mata pelajaran fisika kelas XII IPA SMA Negeri di Kota Baubau

Pembahasan mengenai hasil analisis kualitas soal ujian akhir sekolah mata pelajaran fisika kelas XII IPA SMA Negeri di Kota Baubau berdasarkan reliabilitas. Hasil penelitian melalui aplikasi Iteman yang diperoleh melaui teknik KR-20 diperoleh koefisien reliabilitas instrumen sebesar 0,741, hal ini menunjukkan bahwa indeks reliabilitasnya reliabel. Hasil penelitian ini didukung dengan adanya teori dari Linn dalam tes yang memilih pengecoh tidak lebih dari (Mansyur, 2015) bahwa apabila $\square \mathrm{KR} \square 205 \%$ dari jumlah peserta tes, hal ini berarti keberadaan pengecoh tidak berfungsi.

Jika hasil analisis data tentang tingkat pengecoh dikaitkan dengan kajian teoritis yang dikemukan oleh (Mutia et al., 2014) bahwa keberadaan pengecoh digunakan untuk menjebak terutama bagi mereka yang berkemampuan rendah untuk memilih jawaban yang salah. Adapun yang memiliki kemampuan tinggi tidak akan terkecoh oleh pilihan jawaban yang salah. Hal yang sama juga diungkapkan oleh (Republika, 2009) bahwa pengecoh dapat dikatakan berfungsi apabila pengecoh: a) paling tidak dipilih oleh $5 \%$ peserta, b) lebih banyak dipilih oleh kelompok peserta didik yang belum memahami materi. Hal tersebut juga sama dengan yang dikutarakan oleh (Republika, 2009), bahwa "Butir soal yang baik, pengecohnya akan dipilih secara merata oleh peserta didik yang menjawab salah. Sebaliknya butir soal yang tidak baik, pengecohnya akan dipilih secara acak. Pengecoh dikatakan berfungsi apabila jumlah peserta didik yang memilih pengecoh itu sama atau mendekati jumlah > 0,70 maka soal yang diujikan memiliki reliabilitas yang tinggi, tetapi apabila $\square \mathrm{KR} \square 20<0,70$ maka soal yang diujikan memiliki reliabilitas yang rendah atau tidak reliabel.

Jika hasil penelitian ini dikaitkan dengan tinjauan teoritis sebagaimana yang dikemukakan (Thoha, 2003), reliabilitas sering diartikan dengan keterandalan. Artinya suatu tes memiliki keterandalan bilamana tes tersebut dipakai mengukur berulang-ulang sama, hal ini sejalan dengan yang dikemukakan oleh (Setiyono \& McLeod, 2010) bahwa suatu perangkat ukur jika digunakan dua kali untuk mengukur gejala yang sama memberikan hasil yang relatif sama, maka alat ukur tersebut reliabel. Sedangkan (Lian, 2014) menyatakan bahwa reliabilitas 
merupakan indeks yang menunjukkan sejauhmana suatu alat pengukur dapat dipercaya dan dapat diandalkan. Suatu tes dikatakan memiliki ketetapan jika dapat dipercaya, konsisten/stabil dan produktif kapanpun tes tersebut digunakan.

Berdasarkan hasil analisis data diperoleh bahwa soal ujian akhir sekolah mata pelajaran fisika kelas XII IPA SMA Negeri di Kota Baubau dinyatakan reliabel artinya jika instrumen tersebut digunakan dilain waktu, maka diperkirakan hasilnya akan terpercaya dan konsisten

\section{Kesimpulan}

Validitas isi soal ujian akhir sekolah mata pelajaran fisika kelas XII IPA SMA Negeri se-Kota Baubau telah valid secara isi dengan koefisien validitas isi sebesar 0,943. Validitas kriteria soal ujian akhir sekolah mata pelajaran fisika kelas XII IPA SMA Negeri se-Kota Baubau terdapat 9 butir soal yang tidak valid dari 35 butir soal yang diujikan. Tingkat kesukaran soal ujian akhir sekolah mata pelajaran fisika kelas XII IPA SMA Negeri se-Kota Baubau memiliki sebaran tingkat kesukaran yang tidak proporsional dengan perbandingan sukar, sedang dan mudah adalah 12, 2 dan 21 butir soal. Daya beda soal ujian akhir sekolah mata pelajaran fisika kelas XII IPA SMA Negeri se-Kota Baubau terdapat 14 butir soal yang memiliki daya beda sangat baik, 6 butir soal dengan daya beda baik, 1 butir soal dengan daya beda kurang baik dan 14 butir soal yang memiliki daya beda tidak berfungsi. Efektivitas pengecoh soal ujian akhir sekolah mata pelajaran fisika kelas XII IPA SMA Negeri se-Kota Baubau secara keseluruhan tidak dapat dapat dikatakan efektif atau berfungsi karena dari 35 butir soal yang di ujikan hanya terdapat 2 butir soal yang efektivitas pengecohnya berfungsi. Reliabilitas instrumen tes ujian akhir sekolah mata pelajaran fisika kelas XII IPA SMA Negeri se-Kota Baubau reliabel atau konsisten dengan koefisien reliabilitas instrument tes sebesar 0,741 . 


\section{BIBLIOGRAFI}

Erniwati, Erniwati. Pengembangan Instrumen Penilaian Hasil Belajar Ilmu Pengetahuan Alam Pada Siswa Kelas V Sekolah Dasar Inpres Loka Kabupaten Bantaeng. , (2018).Google Scholar

Fahmi, Ahmad. (2018). Etika Belajar Mengajar Menurut Imam Al-Ghazali (Kajian Kitab Ihya 'Ulumuddin). Universitas Islam Negeri Sumatera Utara. Google Scholar

Kartini, Kartini. (2018). Analisis Kualitas Soal Ujian Sekolah Berstandar Nasional Mata Pelajaran Matematika Di SMK Negeri Kabupaten Bantaeng Berdasarkan Teori Respon Butir. Universitas Negeri Makassar. Google Scholar

Kurniawan, Devi Dwi. (2015). Analisis Kualitas Soal Ujian Akhir Semester Matematika Berdasarkan Teori Respon Butir. Google Scholar

Lian, G. Otawa. (2014). Analisis Kualitas Butir Soal Pilihan Ganda Menurut Teori Tes Klasik dengan Menggunakan Program Iteman. Jurnal Manajemen Pendidikan Islam, 2(2), 231-251. Google Scholar

Mansyur, Rasyid dan Suratno. (2015). Asesmen Pembelajaran di Sekolah. Yogyakarta: Pustaka Belajar.

Mastuti, Rini, Maulana, Syarif, Iqbal, Muhammad, Faried, Annisa Ilmi, Arpan, Arpan, Hasibuan, Ahmad Fauzul Hakim, Wirapraja, Alexander, Saputra, Didin Hadi, Sugianto, Sugianto, \& Jamaludin, Jamaludin. (2020). Teaching from home: Dari belajar merdeka menuju merdeka belajar. Yayasan Kita Menulis. Google Scholar

Mutia, Mutia, Budi, Agus Setyo, \& Serevina, Vina. (2014). Pengembangan Perangkat Pembelajaran Fisika Sma Berbasis Problem Based Learning Sebagai Implementasi Scientific Approach Dan Penilaian Authentic. Prosiding Seminar Nasional Fisika (E-Journal), 3, 169-184. Google Scholar

Otaya, Lian G. (2014). Analisis Kualitas Butir Soal Pilihan Ganda Menurut Teori Tes Klasik Dengan Menggunakan Program Iteman. Google Scholar

Republika. (2009). Siswa dan Guru Resah Adanya UN Ulang.

Ristiyani, Erika, \& Bahriah, Evi Sapinatul. (2016). Analisis kesulitan belajar kimia siswa di SMAN X Kota Tangerang Selatan. Jurnal Penelitian Dan Pembelajaran IPA, 2(1), 18-29. Google Scholar

Sari, Fitria Kumala, Rakimahwati, Rakimahwati, \& Fitria, Yanti. (2019). Hubungan minat dengan hasil belajar peserta didik pada pembelajaran matematika kelas VI SDN 25 Jati Tanah Tinggi. Jurnal Basicedu, 3(2), 397-405. Google Scholar

Setiyono, Budi, \& McLeod, Ross H. (2010). Civil society organisations' contribution to the anti-corruption movement in Indonesia. Bulletin of Indonesian Economic 
Studies, 46(3), 347-370. Google Scholar

Sudaryono, D. (2017). Metodologi Penelitian: Penelitian Kualitatif. Depok: PT. RajaGrafindo Persada, Depok. Google Scholar

Sudjana, Nana. (2009). Penilaian hasil belajar proses belajar mengajar. Bandung: PT Remaja Rosdakarya. Google Scholar

Sukardi, Stevanus K., Zhang, Jie, Burgar, Iko, Horne, Michael D., Hollenkamp, Anthony F., MacFarlane, Douglas R., \& Bond, Alan M. (2008). Prospects for a widely applicable reference potential scale in ionic liquids based on ideal reversible reduction of the cobaltocenium cation. Electrochemistry Communications, 10(2), 250-254. Google Scholar

Suseno, Imam. (2017). Komparasi karakteristik butir tes pilihan ganda ditinjau dari teori tes klasik. Faktor: Jurnal Ilmiah Kependidikan, 4(1), 1-8. Google Scholar

Thoha, M. Chabib. (2003). Teknik Evaluasi Pendidikan, Jakarta: PT. Raja Grafindo Persada. Google Scholar

Wirawan, W. (2016). Evaluasi (teori, metode, metodologi, standar, aplikasi dan profesi). Rajawali Press. Google Scholar

Yuningsih, Heni. (2015). Kebijakan Pendidikan Islam Masa Orde Baru. Tarbiya: Jurnal Ilmu Pendidikan Islam, 1(1), 175-194. Google Scholar

\section{Copyright holder: \\ Minarti Usman (2021)}

First publication right:

Syntax Idea

This article is licensed under:

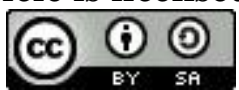

